Marquette University

e-Publications@Marquette

$1-1-2016$

\title{
Accessing Spin-Crossover Behaviour In Iron(II) Complexes Of N-Confused Scorpionate Ligands
}

James R. Gardinier

Marquette University, james.gardinier@marquette.edu

Alexander Richard Treleven

Marquette University

Kristin J. Meise

Marquette University

Sergey Lindeman

Marquette University, sergey.lindeman@marquette.edu

Accepted version. Dalton Transactions, Vol. 45 (2016): 12639-12643. DOI. (C) 2016 The Royal Society of Chemistry. Used with permission. 


\title{
Accessing Spin-Crossover Behaviour In Iron(II) Complexes Of N- Confused Scorpionate Ligands ${ }^{\dagger \ddagger}$
}

\author{
James R. Gardinier \\ Department of Chemistry, Marquette University, \\ Milwaukee, WI \\ Alex R. Treleven \\ Department of Chemistry, Marquette University, \\ Milwaukee, WI \\ Kristin J. Meise \\ Department of Chemistry, Marquette University, \\ Milwaukee, WI \\ Sergey V. Lindeman \\ Department of Chemistry, Marquette University, \\ Milwaukee, WI
}

The first examples of a class of $\mathrm{N}$-confused tris(pyrazolyl)methane 'scorpionate' ligands have been prepared. The magnetic properties of their iron(II) tetrafluoroborate complexes are dictated by changing one substituent per ligand rather than three as is typical for normal scorpionate ligands.

Dalton Transactions, Vol 45 (2016): pg. 12639-12643. DOI. This article is (C) Royal Society of Chemistry and permission has been granted for this version to appear in e-Publications@Marquette. Royal Society of Chemistry does not grant permission for this article to be further copied/distributed or hosted elsewhere without the express permission from Royal Society of Chemistry. 
Investigations into the magnetic properties of $d^{4}-d^{7}$ metal complexes have been partly inspired by the intoxicating allure of developing molecular switches or other innovative technologies that could exploit spin crossover (SCO) behaviour. ${ }^{1}$ For instance, SCO complexes have been employed in thermochromic displays, ${ }^{2}$ show potential as sensors, ${ }^{3}$ MRI contrast agents ${ }^{4}$ and, most recently, in spintronics ${ }^{5}$ and various molecular electronics applications. ${ }^{6}$ Among the sundry of complexes that exhibit SCO behaviour, iron(II) scorpionates (tris(pyrazolyl)borates, ${ }^{7}$ tris(pyrazolyl)methanes, ${ }^{8}$ and related analogues ${ }^{9}$ ) are garnering increased interest because of the simplicity of their syntheses, their high stability, and diverse magnetic behaviour. Notably Trofimenko first showed that $\mathrm{Fe}\left[\mathrm{HB}(\mathrm{pz})_{3}=\mathrm{Tp}\right]_{2}(\mathrm{pz}$ = pyrazol-1-yl) underwent a spin-state change from $S=0$ to $S=2$ above room temperature in solution and the solid state. ${ }^{10}$ In the solid state, the SCO behaviour of the first heating cycle differs from other heating and cooling cycles because of an irreversible phase change on heating from a metastable tetragonal crystal system to a more stable monoclinic system maintained thereafter. ${ }^{11}$ This property can be exploited for the development of read-only memory devices. ${ }^{12}$ The related FeTp* ${ }_{2}\left(\mathrm{Tp}^{*}=\operatorname{tris}(3,5\right.$-dimethylpyrazol-yl)borate) is high spin in solution but undergoes spin crossover and is low spin at $78 \mathrm{~K}$ and below. ${ }^{13}$ The iron(II) complexes of charge-neutral scorpionates such as $\mathrm{Tpm}=\left[\mathrm{HC}(\mathrm{pz})_{3}\right]$ or Tpm* $=\left[\mathrm{HC}\left(\mathrm{pz}^{*}\right)_{3}\right]\left(\mathrm{pz}^{*}=3,5\right.$-dimethylpyrazol-1$\mathrm{yl})$ also show highly variable magnetic behaviour. The compounds $\left[\mathrm{Fe}(\mathrm{Tpm})_{2}\right](\mathrm{X})_{2}\left(\mathrm{X}=\mathrm{PF}_{6},{ }^{14} \mathrm{ClO}_{4},{ }^{15} \mathrm{NO}_{3},{ }^{16} \mathrm{BF}_{4}{ }^{17}\right)$ are low spin at room temperature but undergo SCO above $300 \mathrm{~K}$. [Fe(Tpm* $\left.)_{2}\right]\left(\mathrm{BF}_{4}\right)_{2}$ is high spin at room temperature but undergoes an abrupt SCO at $206 \mathrm{~K}$ in the solid to give a sample with $50 \%$ low-spin sites that originates from a crystallographic phase transition. ${ }^{18}$ Also, one of the two polymorphs of $\left[\mathrm{Fe}(\mathrm{Tpm})\left(\mathrm{Tpm}^{*}\right)\right]\left(\mathrm{BF}_{4}\right)_{2}$ undergoes an abrupt SCO with $\mathrm{T}_{1 / 2}(50 \%$ LS) at $228 \mathrm{~K}$ whereas the other with less efficient solid packing has a gradual spin crossover with $\mathrm{T}_{1 / 2}$ near $300 \mathrm{~K} .{ }^{19}$ Thus, the SCO capabilities of iron(II) scorpionates are profoundly affected by the nature of the 3-pyrazolyl substituents near the metal centre and by their crystal packing. In numerous studies on iron(II) scorpionates, those with pyrazolyl substituents larger than methyls typically either give heteroleptic species ${ }^{20}$ or, if homoleptic, ${ }^{21}$ remain HS, as nicely summarized recently: "...any substituents in the 3-position that are much larger than a methyl destroy any hope of observing spin state

Dalton Transactions, Vol 45 (2016): pg. 12639-12643. DOI. This article is @ Royal Society of Chemistry and permission has been granted for this version to appear in e-Publications@Marquette. Royal Society of Chemistry does not grant permission for this article to be further copied/distributed or hosted elsewhere without the express permission from Royal Society of Chemistry. 
crossover behaviour and essentially lock the complex into the HS form". ${ }^{22}$ While the above statement seems hyperbole, Fe[HB(3-cypropylpz $\left.)_{3}\right]_{2}$ is the only case of a bulkier $\mathrm{Tp}^{\mathrm{R}}$ iron(II) complex to show SCO. ${ }^{7}$ We sought a ligand design that would allow ready (perhaps "on demand") modification of pyrazolyl groups near the metal centre in order to discover new examples of SCO behaviour in scorpionates with bulkier pyrazolyls and to extend the current capabilities of scorpionates as supporting ligands. To that end, we have developed the first of a class of scorpionates whereby one of the pyrazolyl rings is connected to the central $\mathrm{sp}^{3}$-carbon in an unusual fashion, by carbon rather than nitrogen (Fig. 1, left). We term these new ligands $\mathrm{N}$ confused scorpionates in analogy to $\mathrm{N}$-confused porphyrins.

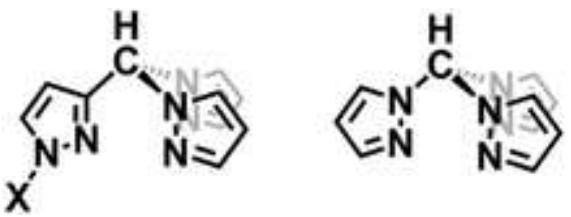

Fig. 1 Left: $\mathrm{N}$-Confused tris(pyrazolyl)methane derivatives reported here $(X=H$, $\mathrm{CH}_{2} \mathrm{C}_{6} \mathrm{H}_{5}=\mathrm{Bn}, \mathrm{p}-\mathrm{SO}_{2} \mathrm{C}_{6} \mathrm{H}_{4} \mathrm{CH}_{3}=\mathrm{Ts}$ ). Right: Normal tris(pyrazolyl)methane.

It is envisioned that these new ligands could permit rapid development of sensors or could introduce new vistas for incorporation of scorpionate complexes into 3D networks. In this communication we detail the syntheses of the ligands and the properties of their homoleptic iron(II) complexes. Future reports will detail ligand variants and the implementation of their metal complexes in assemblies, in sensing applications, and in chemical reactions.

The ligands and iron(II) complexes were prepared as summarized in Scheme 1. The ligand syntheses begins with the known ${ }^{23} \mathrm{H}(\mathrm{pz}) \mathrm{CH}(\mathrm{OMe})_{2}$ that is readily prepared on a 25-50 g scale. The benzyl-protected ligand, ${ }^{B n} \mathrm{~L}$, is obtained in high yield in two steps that ultimately exploits an acid-catalysed condensation reaction between pyrazole and $\mathrm{BnpzCH}(\mathrm{OMe})_{2}$. The resulting ${ }^{\mathrm{Bn}} \mathrm{L}$ is surprisingly unreactive toward typical benzyl deprotecting agents (various catalytic palladium reagents, $\mathrm{H}^{+}$and/or $\mathrm{H}_{2}$ ) but could be oxidatively deprotected in superbasic medium to give very low yields of the protonated ligand ${ }^{H} \mathrm{~L}$. Attention was then turned to a tosyl-protected analogue, ${ }^{\mathrm{T}} \mathrm{L}$, since this species was expected (and found) to be more reliably deprotected under milder conditions. Tosylation of $\mathrm{HpzCH}(\mathrm{OMe})_{2}$ to give $\mathrm{TspzCH}(\mathrm{OMe})_{2}$ proceeded smoothly. Unfortunately, acid-catalysed

Dalton Transactions, Vol 45 (2016): pg. 12639-12643. DOI. This article is @ Royal Society of Chemistry and permission has been granted for this version to appear in e-Publications@Marquette. Royal Society of Chemistry does not grant permission for this article to be further copied/distributed or hosted elsewhere without the express permission from Royal Society of Chemistry. 
condensation with pyrazole to give ${ }^{T s} \mathrm{~L}$ under various conditions (solvent, neat) was unsuccessful because of competing reactions; Tspz is formed along with a mixture of products including $\mathrm{TspzCH}(\mathrm{pz})(\mathrm{OMe})$ and oligo- and polymeric species from self-condensation of $\mathrm{HpzCH}(\mathrm{OMe})_{2}$. Thus, the $\mathrm{CoCl}_{2}$-catalysed Peterson rearrangement ${ }^{24}$ between the aldehyde, $\operatorname{TspzCH}(\mathrm{O})$, and $\mathrm{S}(\mathrm{O}) \mathrm{pz}_{2}$ was used to give the desired ${ }^{\mathrm{T}} \mathrm{L}$. The compound ${ }^{\mathrm{H}} \mathrm{L}$ was obtained in high yield by the reaction between ${ }^{T s} \mathrm{~L}$ and aqueous $5 \mathrm{M} \mathrm{NaOH}$. Importantly, all of the reactions described above can be performed on a large (25-50 g) scale without the need for column chromatography, which makes the new ligands easily accessible.

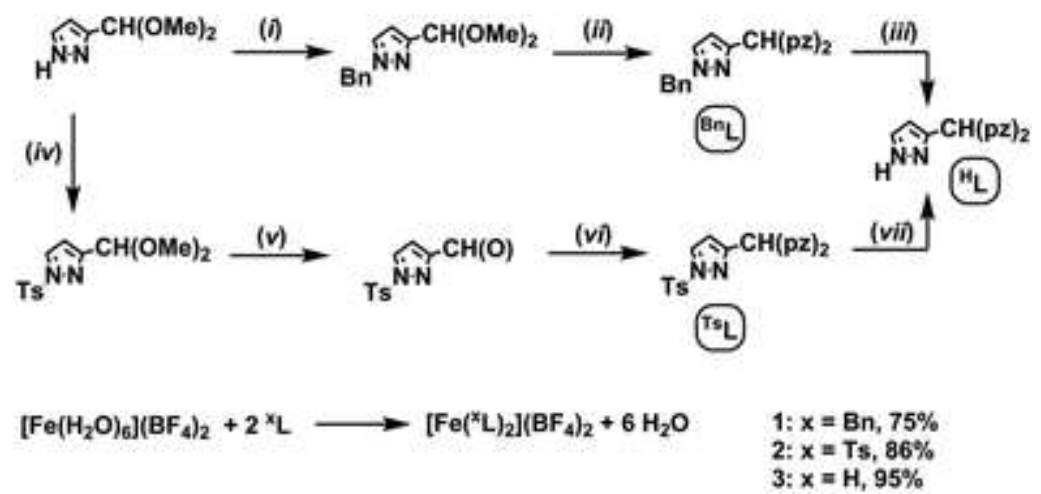

Scheme 1 Preparation of new scorpionates and iron(II) complexes. Key: (i) NaH, $\mathrm{BnBr}$, THF; (ii) $2 \mathrm{Hpz}, 5 \mathrm{~mol} \% \mathrm{pTsOH} \cdot \mathrm{H}_{2} \mathrm{O}, \mathrm{C}_{6} \mathrm{H}_{6}$; (iii) $\mathrm{KO}^{\mathrm{tBu}}$, dmso, $\mathrm{O}_{2}$; (iv) $\mathrm{TsCl}$, $\mathrm{NaOH}, \mathrm{CH}_{2} \mathrm{Cl}_{2}$; (v) cat. $\mathrm{CF}_{3} \mathrm{CO}_{2} \mathrm{H}, \mathrm{H}_{2} \mathrm{O}$, EtOAc; (vi) $\mathrm{S}(\mathrm{O}) \mathrm{pz}_{2}$, cat. $\mathrm{CoCl}_{2}$, THF; (vii) $\mathrm{NaOH}(\mathrm{aq}), \mathrm{THF}, 5 \mathrm{~min}$.

The reaction between $\left[\mathrm{Fe}\left(\mathrm{H}_{2} \mathrm{O}\right)_{6}\right]\left(\mathrm{BF}_{4}\right)_{2}$ and two equivalents of the appropriate ligand, ${ }^{x} \mathrm{~L}$, in either THF or acetone, gave a precipitate which after drying the under vacuum was found to be solvent-free $\left[\mathrm{Fe}\left({ }^{\mathrm{x}} \mathrm{L}\right)_{2}\right]\left(\mathrm{BF}_{4}\right)_{2}[\mathrm{x}=\mathrm{Bn},(\mathbf{1}), \mathrm{x}=\mathrm{Ts},(\mathbf{2}) ; \mathrm{x}=\mathrm{H},(\mathbf{3})]$ according to elemental analyses. The structure of $\mathbf{3}$ was determined at $100 \mathrm{~K}$ by single crystal X-ray diffraction of very small twinned crystals of $\mathbf{3}$ grown by slow evaporation of an aqueous solution. As elaborated in the ESI, $\neq$ the structure is highly disordered (superposition of transand cis-isomers and of anion positions) but the metrics of the $\mathrm{FeN}_{6}$ kernel could be established (Fig. S1止). Most importantly, the average Fe-N bond length (1.968(2) $\AA$ ) is indicative of LS iron(II) and is in accord with magnetic data below. Unfortunately, despite exhaustive attempts (vide infra), it has not yet been possible to grow suitable 
single crystals of solvent-free $\mathbf{1}$ or $\mathbf{2}$ for X-ray diffraction analysis. As solids, $\mathbf{1}$ and $\mathbf{2}$ are colourless and paramagnetic with $\mu_{\mathrm{eff}} \mathrm{ca} .5 .2 \mu_{\mathrm{B}}$ at room temperature and below (SQUID magnetometry, Fig. S2 $\ddagger$ ). Complex $\mathbf{3}$ is a pink solid at room temperature and below but, on heating to about $150{ }^{\circ} \mathrm{C}$, becomes colourless (and reversibly turns pink on cooling). Magnetic measurements over the temperature range $100 \mathrm{~K}$ to $400 \mathrm{~K}$ (high T limit of the magnetometer, Fig. 2) show 3 is fully LS Fe(II) at ca. $200 \mathrm{~K}$, begins SCO at higher temperatures, but is not fully $\mathrm{HS}$ at $400 \mathrm{~K}$. A T $\mathrm{T}_{1 / 2}$ (with $50 \% \mathrm{HS}$ ) of $360 \mathrm{~K}$ can be estimated from the data, which is similar to ca. $380 \mathrm{~K}$ observed for [ $\left.\mathrm{Fe}(\mathrm{Tpm})_{2}\right]\left(\mathrm{BF}_{4}\right)_{2} \cdot{ }^{17}$ Complexes $\mathbf{1}$ and $\mathbf{2}$ are paramagnetic in roomtemperature $\mathrm{CD}_{3} \mathrm{CN}$ solution as indicated by the large chemical shift range ( +60 to $-40 \mathrm{ppm}$ ) of resonances and large solution magnetic moment ( $\mu_{\text {eff }} \mathrm{Ca} .5 .2 \mu_{\mathrm{B}}$, Evan's method). The electronic spectrum of each (Fig. S3 $\ddagger$ ) gives intense high energy band(s) in the UV-region (ca. $\lambda<250 \mathrm{~nm}, \bar{v} \sim 40000 \mathrm{~cm}^{-1}, \varepsilon>20000 \mathrm{M}^{-1} \mathrm{~cm}^{-1}$ ) for intraligand transitions and a characteristic low-energy $\left(\bar{v}<13000 \mathrm{~cm}^{-1}\right)$, lowintensity $\left(\varepsilon<15 \mathrm{M}^{-1} \mathrm{~cm}^{-1}\right) \mathrm{d}-\mathrm{d}$ band for the ${ }^{5} \mathrm{~T}_{2 \mathrm{~g}}-{ }^{5} \mathrm{E}_{\mathrm{g}}$ transition of high-spin iron(II). From average Gaussian fits of the low energy band of several samples, the crystal field splitting $\Delta$ for $\mathbf{1}$ and $\mathbf{2}$ is $12700 \pm$ 100 and $11700 \pm 100 \mathrm{~cm}^{-1}$, respectively. These values are comparable to those found for HS Fe(II) complexes $\left[\mathrm{Fe}(\mathrm{Tpm} *)_{2}\right]^{2+}(12$ $500-14600 \mathrm{~cm}^{-1}$, depending on anion $)^{25}$ or FeTp* ${ }_{2}\left(12700 \mathrm{~cm}^{-1}\right){ }^{13}$ The pink solutions of 3 give paramagnetically shifted ${ }^{1} \mathrm{H}$ NMR spectrum [ $\mu_{\text {eff }}(295 \mathrm{~K}) 0.8 \mu_{\mathrm{B}}$ ] indicative of a small portion of $\mathrm{HS} \mathrm{Fe}(\mathrm{II})$ in solution. As shown in Fig. $\mathrm{S} 4, \pm$ the electronic spectrum of $\mathbf{3}$ in $\mathrm{CH}_{3} \mathrm{CN}$ at $295 \mathrm{~K}$ shows a weak $\left(\varepsilon=1.6 \mathrm{M}^{-1} \mathrm{~cm}^{-1}\right) \mathrm{d}$-d band at $\bar{v}=12600$ $\mathrm{cm}^{-1}$ for a small portion (ca. 10-20\%) presumably of HS 3 overlaid with bands for LS 3. The latter has intense $\left(\varepsilon=10^{3} \mathrm{M}^{-1} \mathrm{~cm}^{-1}\right)$ bands in the near UV range $\left(\bar{v}=30000-37000 \mathrm{~cm}^{-1}\right)$ for CT transitions as well as two lower-energy, low-intensity $d$ - $d$ bands $\left[\lambda_{\max } 525,355 \mathrm{~nm}\right.$; $\varepsilon=50,400 \mathrm{M}^{-1} \mathrm{~cm}^{-1}$, respectively] for ${ }^{1} \mathrm{~A}_{1 \mathrm{~g}}{ }^{-1} \mathrm{~T}_{1 \mathrm{~g}}$ and ${ }^{1} \mathrm{~A}_{1 \mathrm{~g}}{ }^{1}{ }^{1} \mathrm{~T}_{2 \mathrm{~g}}$ transitions that are similar to other LS Fe(II) scorpionate complexes. Variable temperature studies show that the bands for HS $\mathbf{3}$ grow in intensity at the expense of those for LS $\mathbf{3}$ as temperature is raised from $243 \mathrm{~K}$ to $343 \mathrm{~K}$ (Fig. S4 temperature range (Fig. $\mathrm{S} 5$ and $\mathrm{S} 6 \notin$ ) show an increase in magnetic moment from 0.8 to $1.3 \mu_{\mathrm{B}}$ (Evan's), similar to the solid state moment over the same temperature range. From the electronic spectrum, the

Dalton Transactions, Vol 45 (2016): pg. 12639-12643. DOI. This article is (C) Royal Society of Chemistry and permission has been granted for this version to appear in e-Publications@Marquette. Royal Society of Chemistry does not grant permission for this article to be further copied/distributed or hosted elsewhere without the express permission from Royal Society of Chemistry. 
crystal field splitting $\Delta 19050 \mathrm{~cm}^{-1}\left(B=714 \mathrm{~cm}^{-1}\right)$ for LS 3 is comparable to $18700 \mathrm{~cm}^{-1}$ for FeTp 2 and $19200 \mathrm{~cm}^{-1}$ for $\left[\mathrm{Fe}(\mathrm{Tpm})_{2}\right]\left(\mathrm{ClO}_{4}\right)_{2} \cdot{ }^{15,16}$ These data are in agreement with earlier observations that $\Delta$ is about the same for species with similar $\mathrm{Fe}(3,5-$ $\left.\mathrm{R}_{2} \mathrm{pz}\right)_{6}$ kernels, regardless of the bridgehead $\mathrm{HC}$ or $\mathrm{HB}$ of the scorpionate. Overall, comparisons of the data for $\mathbf{3}$ and related scorpionate derivatives show that the connectivity of the pyrazolyl unit only has a small influence on the ligand field strength; the groups at the $\beta$-pyrazolyl positions (3-pyrazolyl or the N1 position of the confused pyrazolyl) have a more prominent influence.

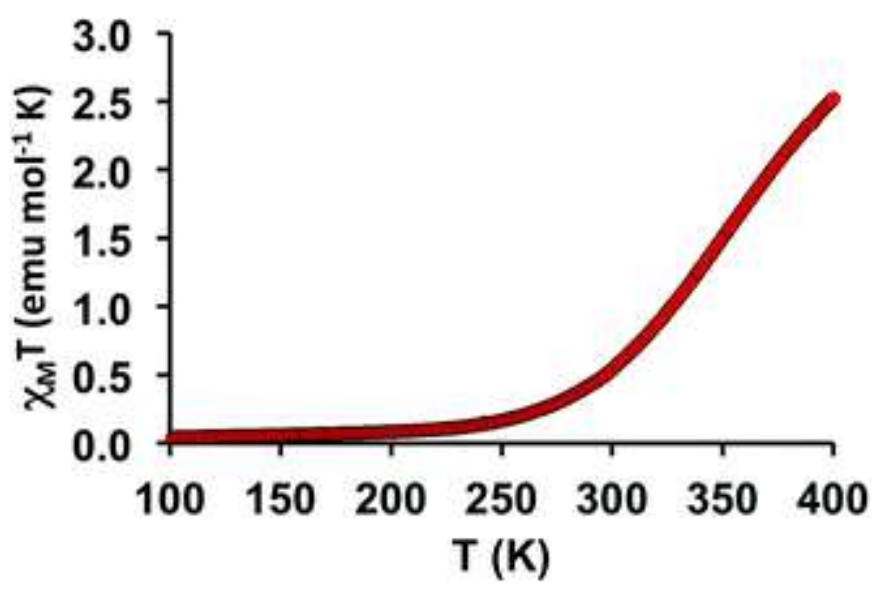

Fig. 2 Temperature dependence of $X_{M} T$ for 3 from SQUID magnetometry measurements.

$\mathrm{Et}_{2} \mathrm{O}$ vapour diffusion into $\mathrm{CH}_{3} \mathrm{CN}$ solutions of either $\mathbf{1}$ or $\mathbf{2}$ gave colourless single crystals of the appropriate di-solvate, $\mathbf{1} \cdot 2 \mathrm{CH}_{3} \mathrm{CN}$ or $2 \cdot 2 \mathrm{CH}_{3} \mathrm{CN}$ suitable for X-ray diffraction. The structure of $\mathbf{1} \cdot 2 \mathrm{CH}_{3} \mathrm{CN}$ shows a pseudo octahedral metal center the two benzyl-protected pyrazolyl rings trans- to each other, Fig. 3. The Fe-N bond distance associated with the confused pyrazolyl (Fe-N2, 2.006(1) $\AA$ ) is longer than those with the regular pyrazolyls (Fe-N11, 1.974(1) and Fe-N21, $1.975(1) \AA$ ). The average Fe-N distance of $1.985(1) \AA$ is consistent with LS Fe(II). Finally, as shown in Fig. S7, $\neq$ the supramolecular structure shows sheets of $\mathbf{1}$ parallel with the bc-plane stacked along the a-axis so as to form channels along c-where solvated $\mathrm{CH}_{3} \mathrm{CN}$ molecules reside. Presumably, the weak van der Waals forces associated with these molecules permits the solvent to be easily removed under application of vacuum. Unfortunately, attempts to

Dalton Transactions, Vol 45 (2016): pg. 12639-12643. DOI. This article is (C) Royal Society of Chemistry and permission has been granted for this version to appear in e-Publications@Marquette. Royal Society of Chemistry does not grant permission for this article to be further copied/distributed or hosted elsewhere without the express permission from Royal Society of Chemistry. 
obtain structures at higher temperatures were thwarted by weak diffraction, disorder of solvent and benzyl rings that seriously compromised quality below publication standards.

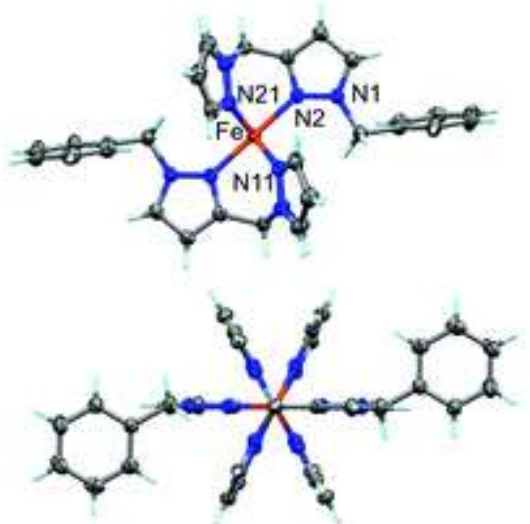

Fig. 3 Two views of the solid state structure of the dication in $\mathbf{1} \cdot 2 \mathrm{CH}_{3} \mathrm{CN}$. Thermal ellipsoids shown at $30 \%$ probability.

The structure of $\mathbf{2} \cdot 2 \mathrm{CH}_{3} \mathrm{CN}$ at $100 \mathrm{~K}$ (Fig. S8 \pm ) shows an average Fe-N distance of 2.214(1) $\AA$ that is in accord with HS Fe(II). Again, the Fe-N bond associated with the confused pyrazolyl is significantly longer than the other two on the same ligand $(2.406(1)$ versus $2.112(1)$ and $2.123(1) \AA$ ) and is trans- to the same ring on the other ligand bound to iron. The larger steric bulk of the tosyl versus benzyl causes greater pyrazolyl ring twisting in the former (avg. FeN$\mathrm{NC}_{\text {methine }}=8.3^{\circ}$ versus $3.8^{\circ}$ for $1 \cdot 2 \mathrm{CH}_{3} \mathrm{CN}$ ), presumably hindering spin crossover.

The spin crossover behaviour of a sample of solid $1 \cdot 2 \mathrm{CH}_{3} \mathrm{CN}$ freshly crystallized, decanted, and dried under a $\mathrm{N}_{2}$ stream (to minimize solvent loss by vacuum drying) was interrogated by SQUID magnetometry over the temperature range 2 to $300 \mathrm{~K}$ (Fig. 4). The sample is clearly HS from $300 \mathrm{~K}$ to about $175 \mathrm{~K}$ with $\mu_{\text {eff }}=5.1 \mu_{\mathrm{B}}$. Below $175 \mathrm{~K}$ the sample undergoes a gradual spin state change and reaches a minimum effective moment of $\mu_{\text {eff }}=1.7 \mu_{\mathrm{B}}$ at $60 \mathrm{~K}$. This residual moment differs from the typical value of $0.7 \mu_{\mathrm{B}}$ of iron(II) scorpionates (see Fig. 2) that arises from temperature independent paramagnetism ( $2^{\text {nd }}$ order Zeeman effect on paramagnetism). Since the data were identical regardless of heating/cooling rates thus the HS state is not kinetically trapped, ${ }^{26}$ we attribute the excess moment (ca. 
$1 \mu_{\mathrm{B}}$ ) of the analytically pure sample to about a $7-10 \% \mathrm{HS} \mathrm{Fe}(\mathrm{II})$ that arises due either to unavoidable desolvation during drying and transfer to the magnetometer, to a portion of a yet-to-be-identified cis-isomer that may not undergo SCO, or to both. We favour the former given the variability in data when samples are subjected to different evacuation and handling procedures (Fig. S9 $\ddagger$ ). Regardless, the magnetic properties of $\mathbf{1} \cdot 2 \mathrm{CH}_{3} \mathrm{CN}$ are clearly different than its desolvated counterpart $\mathbf{1}$ at low temperature and provide yet another example that solvate molecules can have a profound impact on SCO behaviour. The data are also significant as they demonstrate only the second example of SCO behaviour in a scorpionate that has a pyrazolyl substituent larger than a methyl proximal ( $\beta-)$ to the metal centre.

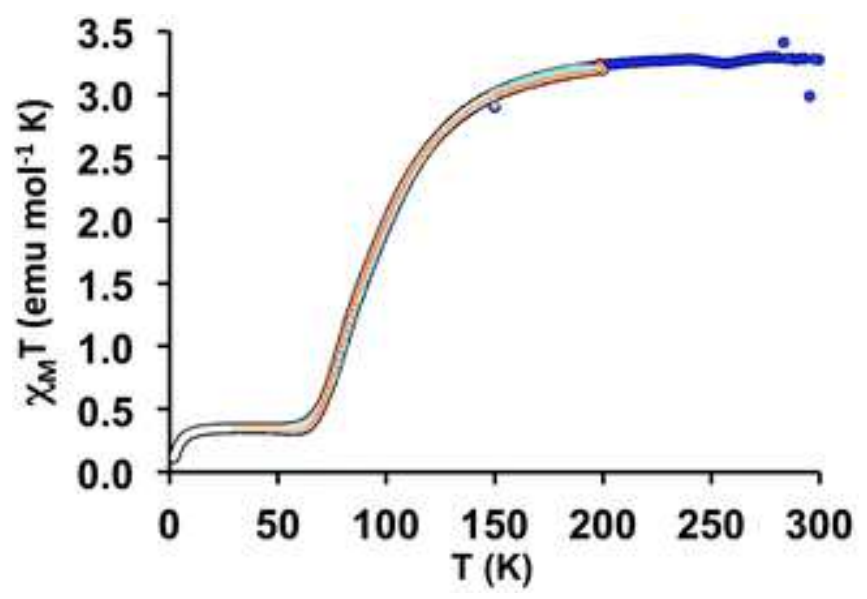

Fig. 4 Variable temperature magnetic data for $1 \cdot 2 \mathrm{CH}_{3} \mathrm{CN}$. Key: Blue and light blue, first and second cooling cycle; red and orange, first and second heating cycle.

In summary, we have developed a multigram synthesis of the first example of a class of $\mathrm{N}$-confused scorpionate ligand. In this first example, one pyrazolyl of a tris(pyrazolyl)methane is tethered to the $\mathrm{sp}^{3}$-methine carbon via a carbon rather than via the nitrogen of the heterocycle. One can envision other examples where two or all three pyrazolyls are connected to the methine carbon (or to a boron centre) in this fashion. This new ligand design opens the door synthetically to a wealth of nitrogen protection/deprotection reactions that could allow easy modification of the steric and electronic properties about the metals' first and second coordination sphere. In the current case we have altered one $\beta$-pyrazolyl substituent of the ligand (on the exo- $\mathrm{N}$ ) to be an $\mathrm{H}, \mathrm{Bn}$, or Ts group. Each gave $\left[\mathrm{Fe}\left({ }^{\times} \mathrm{L}\right)_{2}\right]^{2+}$ complexes, thereby 
showing a steric limit to such homoleptic moieties has not been breached by these small to modest-size groups. The electronic properties of these ligands compare favourably with both Tp and Tpm based scorpionates. The complexes $\left[\mathrm{Fe}\left({ }^{\mathrm{x}} \mathrm{L}\right)_{2}\right]\left(\mathrm{BF}_{4}\right)_{2}$ exhibit a range of magnetic behaviour with the case of $\mathrm{x}=\mathrm{H}$ showing $\mathrm{SCO}$ behaviour near room temperature and above, in contrast to those with larger groups, $x=B n$ or Ts, that remain high spin. The derivative $x=B n$ can be induced to show SCO behaviour (with $\mathrm{T}_{1 / 2} \mathrm{ca} .90 \mathrm{~K}$ ) by crystallization with acetonitrile. It is hypothesized that the crystal packing in the solvate is such that the pyrazolyl rings are free to relax to give shorter Fe-N bonds and lower ring twisting associated with LS $\mathrm{Fe}$ (II) but the solvent-free complex may be more tightly packed and have more twisted pyrazolyl rings that prevents SCO behaviour. Unfortunately, the high mp of $\mathrm{CH}_{3} \mathrm{CN}$ (225 K) precludes observation of SCO of $\mathbf{1}$ in solution (which may be expected to occur near $90 \mathrm{~K}$, similar to the solid). The details of full structural investigations to test the above hypothesis and to delineate solvent and anion effects will be reported in due course. The reaction chemistry of metal complexes based on these and other, bulkier derivatives will be described elsewhere.

\section{Notes and references}

${ }^{1}$ Selected reviews: S. Hayami, S. M. Holmes and M. A. Halcrow, J. Mater. Chem. C, 2015, 3, 7775-7778 Spin-Crossover Materials: Properties and Applications, ed. Malcolm A. Halcrow, John Wiley \& Sons, Ltd., West Sussex, 2013; M. A. Halcrow, Chem. Soc. Rev., 2011, 40, 41194142; G. J. Long, F. Grandjean and D. L. Reger, Top. Curr. Chem., 2004, 233, 91-122. Spin crossover in transition metal compounds II P. Gütlich and H. A. Goodwin, Top. Curr. Chem., 2004, 234, 1-47.

${ }^{2}$ O. Kahn and C. J. Martinez, Science, 1998, 279, 44-48.

${ }^{3}$ R. G. Miller and S. Brooker, Chem. Sci., 2016, 7, 2501-2505; G. Galle, D. Deldicque, J. Degert, T. Forestier, J.-F. Letard and E. Freysz, Appl. Phys. Lett., 2010, 96, 041907/1; Z. Ni and M. P. Shores, J. Am. Chem. Soc., 2009, 131, 32-33.

${ }^{4}$ I.-R. Jeon, J. G. Park, C. R. Haney and T. D. Harris, Chem. Sci., 2014, 5, 2461-2465; R. N. Muller, L. Van der Elst and S. Laurent, J. Am. Chem. Soc., 2003, 125, 8405-8407.

5]. Huang, R. Xie, W. Wang, Q. Li and J. Yang, Nanoscale, 2016, 8, 609-616; M. Bernien, H. Naggert, L. M. Arruda, L. Kipgen, F. Nickel, J. Miguel, C.

Dalton Transactions, Vol 45 (2016): pg. 12639-12643. DOI. This article is (C) Royal Society of Chemistry and permission has been granted for this version to appear in e-Publications@Marquette. Royal Society of Chemistry does not grant permission for this article to be further copied/distributed or hosted elsewhere without the express permission from Royal Society of Chemistry. 
F. Hermanns, A. Krüger, D. Krüger, E. Schierle, E. Weschke, F. Tuczek and W. Kuch, ACS Nano, 2015, 9, 8960-8966.

${ }^{6} \mathrm{M}$. Gruber, V. Davesne, M. Bowen, S. Boukari, E. Beaurepaire, W. Wulfhekel and T. Miyamachi, Phys. Rev. B: Condens. Matter, 2014, 89, 195415; T. Miyamachi, M. Gruber, V. Davesne, M. Bowen, S. Boukari, L. Joly, F. Scheurer, G. Rogez, T. K. Yamada, P. Ohresser, E. Beaurepaire and W. Wulfhekel, Nat. Commun., 2012, 938, 1-6; T. G. Gopakumar, F. Matino, H. Naggert, A. Bannwarth, F. Tuczek and R. Berndt, Angew. Chem., Int. Ed., 2012, 51, 6262-6266; M. S. Alam, M. Stocker, K. Gieb, P. Müller, M. Haryono, K. Student and A. Grohmann, Angew. Chem., Int. Ed., 2010, 49, 1159-1163; A. Bousseksou, G. Molnár, P. Demont and J. Menegotto, J. Mater. Chem., 2003, 13, 2069-2071.

7D. L. Reger, J. R. Gardinier, J. D. Elgin, M. D. Smith, D. Hautot, G. J. Long and F. Grandjean, Inorg. Chem., 2006, 45, 8862-8875.

${ }^{8}$ L. G. Lavrenova and O. G. Shakirova, Eur. J. Inorg. Chem., 2013, 670-682.

${ }^{9}$ S. E. Creutz and J. C. Peters, Inorg. Chem., 2016, 55, 3894-3906; I. Kuzu, I. Krummenacher, I. J. Hewitt, Y. Lan, V. Mereacre, A. K. Powell, P. Höfer, J. Harmer and F. Breher, Chem. - Eur. J., 2009, 15, 43504365.

${ }^{10}$ J. P. Jesson, S. Trofimenko and D. R. Eaton, J. Am. Chem. Soc., 1967, 89, 3158-3167; G. J. Long and B. B. Hutchinson, Inorg. Chem., 1987, 26, 608-613; F. Grandjean, G. J. Long, B. B. Hutchinson, L. Ohlhausen, P. Neill and J. D. Holcomb, Inorg. Chem., 1989, 28, 4406-4414.

${ }^{11}$ L. Salmon, G. Molnár, S. Cobo, P. Oulié, M. Etienne, T. Mahfoud, P. Demont, A. Eguchi, H. Watanabe, K. Tanaka and A. Bousseksou, New J. Chem., 2009, 33, 1283-1289.

${ }^{12}$ T. Mahfoud, G. Molnár, S. Cobo, L. Salmon, C. Thibault, C. Vieu, P. Demont and A. Bousseksou, Appl. Phys. Lett., 2011, 99, 053307.

13]. D. Oliver, D. F. Mullica, B. B. Hutchinson and W. O. Milligan, Inorg. Chem., 1980, 19, 165-169; D. C. L. De Alwis and F. A. Schultz, Inorg. Chem., 2003, 42, 3616-3622.

${ }^{14} \mathrm{H}$. Winkler, A. X. Trautwein and H. Toftlund, Hyperfine Interact., 1992, 70, 1083-1086.

15]. J. McGarvey, H. Toftlund, A. H. R. AI-Obaidi, K. P. Taylor and S. E. J. Bell, Inorg. Chem., 1993, 32, 2469-2412.

${ }^{16}$ P. Anderson, T. Astley, M. Hitchman, F. Keene, B. Moubaraki, K. S. Murray, B. Skelton, E. Tiekink, H. Toftlund and A. White, J. Chem. Soc., Dalton Trans., 2000, 3505-3512.

${ }^{17}$ D. L. Reger, C. A. Little, A. L. Rheingold, M. Lam, L. M. Liable-Sands, B. Rhagitan, T. Concolino, A. Mohan, G. J. Long, V. Briois and F. Grandjean, Inorg. Chem., 2001, 40, 1508-1520; V. Briois, P. Sainctavit, G. J. Long and F. Grandjean, Inorg. Chem., 2001, 40, 9198.

Dalton Transactions, Vol 45 (2016): pg. 12639-12643. DOI. This article is (C) Royal Society of Chemistry and permission has been granted for this version to appear in e-Publications@Marquette. Royal Society of Chemistry does not grant permission for this article to be further copied/distributed or hosted elsewhere without the express permission from Royal Society of Chemistry. 
NOT THE PUBLISHED VERSION; this is the author's final, peer-reviewed manuscript. The published version may be accessed by following the link in the citation at the bottom of the page.

${ }^{18}$ D. L. Reger, C. A. Little, V. G. Young Jr. and M. Pink, Inorg. Chem., 2001, 40, 2870-2874.

${ }^{19}$ B. Moubaraki, B. A. Leita, G. J. Halder, S. R. Batten, P. Jensen, J. P. Smith, J. D. Cashion, C. J. Kepert, J.-F. Létard and K. S. Murray, Dalton Trans., 2007, 4413-4426.

${ }^{20} \mathrm{H}$. Park, J. S. Baus, S. V. Lindeman and A. T. Fiedler, Inorg. Chem., 2011, 50, 11978-11989.

${ }^{21}$ P. Checchi, M. Berrettoni, M. Giorgetti, G. G. Lobbia, S. Calogero and L. Stievano, Inorg. Chim. Acta, 2001, 318, 67-76; D. M. Eichorn and W. H. Armstrong, Inorg. Chem., 1990, 29, 3607-3612.

${ }^{22}$ M. A. Goodman, A. Y. Nazarenko, B. J. Casavant, Z. Li, W. W. Brennessel, M. J. DeMarco, G. Long and M. S. Goodman, Inorg. Chem., 2012, 51, 1084-1093.

${ }^{23}$ S. M. Allin, W. R. S. Barton, W. R. Bowman, E. Bridge, M. R. J. Elsegood, T. McInally and V. McKee, Tetrahedron, 2008, 64, 7745-7758.

${ }^{24}$ K. I. Thé and L. K. Peterson, Can. J. Chem., 1973, 51, 422-426; K. I. Thé, L. K. Peterson and E. KiehImann, Can. J. Chem., 1973, 51, 24482451; L. K. Peterson, E. Kiehlmann, A. R. Sanger and K. I. Thé, Can. J. Chem., 1974, 52, 2367-2374.

${ }^{25}$ O. G. Shakirova, L. G. Lavrenova, A. S. Bogomyakov, K. Yu. Zhizhin and N. T. Kuznetsov, Russ. J. Inorg. Chem., 2015, 60, 786-789; L. G. Lavrenova, A. D. Strekalova, A. V. Virovets, D. A. Piryazev, V. A. Daletskii, L. A. Sheludyakova, T. F. Mikhailovskayac and S. F. Vasilevskiic, Russ. J. Coord. Chem., 2012, 38, 507-514; L. G. Lavrenova, A. V. Virovets, E. V. Peresypkina, A. D. Strekalova, D. A. Piryazev, V. A. Daletsky, L. A. Sheludyakova and S. F. Vasilevsky, Inorg. Chim. Acta, 2012, 382, 1-5.

${ }^{26}$ G. Ritter, E. Koenig, W. Irler and H. A. Goodwin, Inorg. Chem., 1978, 17, 224-228.

\section{Footnotes}

† This paper is dedicated to Prof. Dan Reger on the occasion of his retirement.

\# Electronic supplementary information (ESI) available: Experimental procedures, crystal data, other characterization data. CCDC 1478564, 1478566 and 1478567 for $\mathbf{1} \cdot 2 \mathrm{CH}_{3} \mathrm{CN}, \mathbf{2} \cdot \mathrm{CH}_{3} \mathrm{CN}$ and 3. For ESI and crystallographic data in CIF or other electronic format see DOI: $10.1039 / \mathrm{c} 6 \mathrm{dt} 01898 \mathrm{j}$

Dalton Transactions, Vol 45 (2016): pg. 12639-12643. DOI. This article is (C) Royal Society of Chemistry and permission has been granted for this version to appear in e-Publications@Marquette. Royal Society of Chemistry does not grant permission for this article to be further copied/distributed or hosted elsewhere without the express permission from Royal Society of Chemistry. 